\title{
The Growth of One Year-Old Oil Palms Intercropped with Soybean and Groundnut
}

\author{
Eka Tarwaca Susila Putra (Corresponding author) \\ Department of Agronomy, Faculty of Agriculture, Universitas Gadjah Mada \\ Bulaksumur, Yogyakarta 5281, Indonesia \\ Tel: 62-821-3634-5738 E-mail: muamariqbal@yahoo.com \\ Arif Faisal Simatupang \\ Department of Agronomy, Faculty of Agriculture, Universitas Gadjah Mada \\ Bulaksumur, Yogyakarta 55281, Indonesia
}

Tel: 62-274-551-228Ｅ-mail: faessallass@yahoo.com

Supriyanta

Department of Plant Breeding, Faculty of Agriculture, Universitas Gadjah Mada

Bulaksumur, Yogyakarta 55281, Indonesia

Tel: 62-817-285-7144Ｅ-mail: antosupri@lycos.com

Sriyanto Waluyo

Department of Agronomy, Faculty of Agriculture, Universitas Gadjah Mada

Bulaksumur, Yogyakarta 55281, Indonesia

Tel: 62-812-293-2944

Didik Indradewa

Department of Agronomy, Faculty of Agriculture, Universitas Gadjah Mada

Bulaksumur, Yogyakarta 55281, Indonesia

Tel: 62-812-159-4720Ｅ-mail: didikindradewa@yahoo.com

Received: December 21, 2011 Accepted: January 5, $2012 \quad$ Online Published: April 1, 2012

doi:10.5539/jas.v4n5p169

URL: http://dx.doi.org/10.5539/jas.v4n5p169

The research is financed by Faculty of Agriculture, Universitas Gadjah Mada. No. 2007-1(Sponsoring information)

\begin{abstract}
The objective of this research was to determine appropriate annual food crops in the areas of a year-old oil palm. Field trials were arranged in a single factor of randomized completely block design. A factor to be tested was the species of annual food crops, namely, soybeans and groundnuts. Controls in this study were monocultures of oil palm, soybean and groundnuts. The results showed that soybean and groundnut could give high yields when planted between rows of one year-old oil palms, which were similar to the yield of those crops in the monoculture system. In addition, the presence of soybean and groundnut between the rows of one year-old oil palms was found not inhibiting the growth rate and development of oil palms as the main crop. On the contrary, there was a tendency that the oil palms planted with soybeans and groundnut to grow faster than those planted in monoculture.
\end{abstract}


Keywords: Growth, Yield, Oil palm, Soybean, Groundnut, Intercropping

\section{Introduction}

Oil palm is the most important plantation commodity in Indonesia. In 2010, oil palm areas reached 9 million hectares, with the production and productivity of 19.5 million tonnes per year and 35 tonnes per ha/year. At this time, the expansions of oil palm areas were continued, specifically in Sumatra, Kalimantan and Papua (MoA, 2011). The areas of $1-3$ year-old oil palms, often referred to as immature plants, still have wide empty spaces among the rows of oil palms. This is similar for the areas of $4-5$ year-old oil palms, which are often referred to as young matured oil palms. $1-5$ year-old oil palms are also commonly referred to as young plants (SMARTRI, 2005; Corley and Tinker, 2003). The wide empty spaces among the rows of young oil palms have resulted in ineffective or inefficient utilization of environmental resources, such as land, growing space, sunlight and $\mathrm{CO}_{2}$ (Rezig et al, 2010).

Thus, the introduction of annual crops, such as soybean and groundnut in young oil palm plantation areas, has provided the opportunity to improve the efficiency and effective uses of environmental resources (Aynehband et al, 2010; Rezig et al, 2010; Abera and Feyisa, 2009; Amanullah et al, 2006). Meanwhile, the components of the young oil palm ecosystem are also more diverse with the introduction of the annual crops within the empty spaces among the rows of main crop. The increasing diversity of the ecosystem components has given impacts on the improvement of land capability to save water and $\mathrm{CO} 2$, and solar radiation harvesting (Chianeh et al, 2011; Rezvani et al, 2011; Prasad and Brook, 2005). Therefore, the introduction of annual crops has caused the ecosystem health in young oil palm areas to become better. In the long term, the young oil palm areas will be enriched with annual crops and have a chance to address global warming due to the increased capacity in the amount of $\mathrm{CO}_{2}$ harvested by the ecosystem (Rezig et al, 2010). Other opportunities that can be captured through the introduction of the annual crops were to make young oil palm plantation areas as a buffer of food production. Food production is derived from the introduction of the annual crops.

The explanations in the previous paragraph indicate that the young oil palm areas are strategic and have a major role in solving global warming and food insecurity. This is supported by its great areas, especially in Indonesia. The statistical data in 2010 showed that the area of young oil palms reached 1.8 million hectares and was expected to rise in the coming years because of the continuous activities of extensification (MoA, 2011).

The enrichment model of the components of young oil palm ecosystem, through the introduction of annual food crops, is a technology that can be used to improve the effectiveness and efficiency of the use of environmental resources (Rezvani et al, 2011; Rezig et al, 2010). However, strategies need to be found, so that the introduction of the annual food crops will not interfere with the growth and development of young oil palms as the main crop (Khan et al, 2007). The introduction of annual crops was based on the availability of the environmental resources in the area of young oil palms (aged 1-5 years), and this is one of the strategies that can be applied (Celette et al, 2009; Ghosh et al, 2006). It is important to highlight that the right type of the annual crop(s) will not interfere with the growth and development of oil palms; on the contrary, a positive interaction between young oil palms and the annual food crops actually has a good chance to accelerate growth and development of the main crop. Meanwhile, the selection of appropriate annual crops will also optimize food production because those crops have optimal growth, development and yield (Singer et al, 2007; Szumigalski and Akcer, 2006; Haby et al, 2006). Nonetheless, the type the appropriate seasonal crops are allegedly different in oil palm plantations aged 1, 2, 3, 4 and 5 years since the composition of the environmental resources vary between the phases of oil palm development.

Based on the above explanations, research is needed to determine the appropriate annual food crops in the areas of one year-old oil palms. The focus of the current study was the one year-old oil palm plantations. The selected crops have the following criteria: (1) have optimal growth, development and productivity under one year-old oil palms, (2) have the ability as a buffer of nutrient status in the plantation areas, and (3) are able to accelerate the growth and development of one year-old oil palms as the main crop.

\section{Methodology}

Research was carried out between September 2007 and April 2008 at a one year-old oil palm plantation in PTPN VIII, Sang Hyang Damar area, Picung District, Pandeglang Region, Banten Province. Field trials were arranged in a single factor of randomized completely block design (RCBD), using three blocks as a replication. The factor to be tested was the species of the annual food crops, namely, soybeans and groundnuts. The controls in this study were the monocultures of oil palm plantations (i.e. free of all kinds of food crops), soybean and groundnuts. In the treatment which involved oil palm plantations, 3 hectares of one year-old oil palm plantation were used. Therefore, each block contained a hectare of oil palm plantation, and a stretch of land for monoculture soybean 
and groundnuts. The field has a flat topography to ensure an easier blocking. In each block, the treatments were randomized, i.e. Control 1 (monoculture of oil palm), Control 2 (monoculture of soybean), Control 3 (monoculture of groundnuts), oil palms intercropped with soybeans and groundnuts, so that the area per treatment within a block would be $3333 \mathrm{~m} 2$. The planting distance for soybeans and groundnuts in this study was $20 \mathrm{~cm} \times 20 \mathrm{~cm}$. The fertilizer doses of soybeans and groundnuts intercropped with one year-old oil palms were according to the optimal dose as in the monoculture. The doses of urea, SP-36, and $\mathrm{KCl}$ were $100 \mathrm{~kg} / \mathrm{ha}$, and all were given at the same time with the planting date. In the meantime, control of pests and diseases was carried out using prevention strategy.

Data collection was conducted on several variables, namely, microclimate conditions, growth and development of oil palm, as well as growth, development and yields of soybean and groundnuts. Microclimate variable was observed on rainfall, rainy days, light intensity, air temperature and relative humidity in the research area. The growth and development variables of oil palms were measured on the length and stem diameter, number and area of leaf and dry weight of stems, leaves and shoot. Meanwhile, measurements of the leaf area and plant dry weight of oil palm were based on non-destructive methods, which were developed by Corley and Tinker (2003). Plant growth analysis variables [namely, leaf area index (LAI), net assimilation rate (NAR) and plant growth rate (PGR, without roots)] were derived from the growth variables of oil palms. Meanwhile, plant height, number and area of leaf, stem diameter, shoot and root dry weight, total root length, yield components weight (including the number and weight of pods per plant, weight of 100 seeds and grain weight per plant), as well as grain dry weight (per plot and hectare) were measured on the soybeans and groundnuts. Furthermore, the plant growth analysis of soybeans and groundnuts, which included leaf area index (LAI), net assimilation rate (NAR), crop growth rate (CGR) and harvest index (HI), were calculated based on the variables which had been measured from both the plants. Land equivalent ratio (LER) on intercropping of oil palm - soybean and oil palm groundnuts was calculated based on the shoot dry weight of oil palms during the study, as well as the grain yield per hectare of soybeans and groundnuts. The LER was calculated using the following equation:

$$
\mathrm{LER}=(\mathrm{Yab} / \mathrm{Yaa})+(\mathrm{Yba} / \mathrm{Ybb})
$$

Notes:

Yaa $=$ accretion of shoot dry weight of oil palm during the study in the monoculture $(\mathrm{kg} / \mathrm{ha})$

$\mathrm{Ybb}=$ grain yield per hectare of soybean/groundnut in the monoculture $(\mathrm{kg} / \mathrm{ha})$

$\mathrm{Yab}=$ accretion of shoot dry weight of oil palms when intercropped with soybean $/$ groundnut $(\mathrm{kg} / \mathrm{ha})$

$\mathrm{Yba}=$ grain yield per hectare of soybeans/groundnuts intercropped with oil palms $(\mathrm{kg} / \mathrm{ha})$

LER was used to estimate the influence of competition and advantage of intercropping in comparison to monoculture. If LER $>1$, it means intercropping is more profitable than monoculture, and vice versa (Palaniappan, 1985).

The data were analyzed using the Analysis of Variance (ANOVA) at 5\% level and continued with the Duncan's Multiple Range Test (DMRT), if the result was found to be significant. All the analyses were performed using the General Linear Model Procedure (PROC GLM) (SAS Institute, 1990).

\section{Results}

The analysis of soil chemical properties showed that the field has an optimal $\mathrm{pH}(6.46)$, nitrogen $(\mathrm{N}, 0.69 \%)$, potassium (K, $0.48 \mathrm{meq} / 100 \mathrm{~g}$ ), and cation exchange capacity (CEC, $30.93 \mathrm{meq} / 100 \mathrm{~g}$ ) for the growth and development of oil palms, as well as the annual food crops (see Table 1). Nevertheless, the contents of phosphorus $\left(\mathrm{P}_{2} \mathrm{O}_{5}, 6.07 \mathrm{mg} / 100 \mathrm{~g}\right)$, carbon $(\mathrm{C}, 1.83 \%)$ and organic matter $(\mathrm{OM}, 3.10 \%)$ in the field were not ideal to support plant growth and development because the values were quite low. As for the texture and composition of soil fractions, the field used in this study was found to be ideal for the growth and development of oil palms as well as for the annual food crops. In particular, the field has clay-loam texture; the compositions of sand, clay and dust were $33.01 \%, 34.33 \%$ and $32.66 \%$, respectively.

The average daily temperature and humidity at the research site reached $30.08 \mathrm{oC}$ and $54.98 \%$ (see Table 2). Meanwhile, the light intensity was in the range of 88.30 - $91.00 \%$ (see Table 2). At the research site, rainfalls reached $1306 \mathrm{~mm}$ in September 2007 - January 2008 (see Table 2). Nevertheless, the high temperature and low humidity at the research site are not ideal for the growth and development of oil palms, as well as annual food crops. On the contrary, the research site has a high level of light intensity and rainfalls, so the research site is ideal to support the growth and development of oil palms and the annual food crops from both the environmental variables. 
The data analysis for the plant growth variables of oil palms, which included leaf area index (LAI), net assimilation rate (NAR), crop growth rate (CGR) and dry weight of stems, leaves and total shoots, showed that these variables were not influenced by planting pattern. It was found that the oil palms intercropped with soybeans or groundnuts had the same growth rate as those planted in the monoculture system (see Table 3). In fact, there was observed that intercropping with soybeans could improve CGR and NAR of oil palm. The improvements in both the CGR and NAR were followed by the increase in the dry weight of oil palms.

The number of leaves of oil palm planted in the monoculture and intercropping areas was similar, either intercropped with soybeans or groundnuts (see Figure 1). Meanwhile, oil palms intercropped with soybeans have higher trunks compared to those intercropped with groundnut or in the monoculture. Nevertheless, this finding could not be used as an indicator showing that the intercropping system has a positive effect on the height rate of oil palms. This is particularly because oil palms intercropped with soybeans were initially higher than those that were intercropped with groundnuts or in monoculture of oil palms (see Figure 1). Similarly, the significant effect of the planting pattern could be detected in the diameter of oil palm trunks. Oil palms that were intercropped with soybeans were observed to have higher stem diameter compared to those intercropped with groundnuts or in monoculture (see Figure 1). Meanwhile, the stem diameter of oil palms intercropped with groundnuts was similar to those in the monoculture.

Data gathered for the growth of soybean indicated that the monoculture of soybean yielded the same growth rate with soybeans intercropped with one year-old oil palms (see Table 4). Soybeans grown and intercropped with oil palms had the number of leaves, LAI, NAR, CGR, total root length, root and plant dry weight, plant height and stem diameter as large as those of the monoculture.

In line with the data on growth, the yield and yield components of soybean grown in monoculture were as large as those grown intercropping with one year-old oil palms (see Table 5). In particular, soybean grown intercropping with one year-old oil palm produced similar number of pods, weight of pods and seed weight per plant, 100 seed weight and seed yield per hectare with the monoculture of soybean. Based on the growth and yield of soybean (Tables 4 and 5), it was found to possess the potential to be developed in the area of one year-old oil palms.

Meanwhile, groundnut has an optimal growth when intercropped with one year-old oil palms. Groundnut that was planted intercropping with oil palms had an equivalent growth rate compared to that of the monoculture (see Table 6). In fact, for several growth variables (e.g., plant height and stem diameter), groundnuts planted intercropping with oil palms had higher stems and greater stem diameter than those in the monoculture system. These conditions indicated that the growth of plant was not inhibited even though groundnuts were grown under the stand of oil palms.

Thus, it could be stated that groundnuts provide high yields when intercropped with one year-old oil palms. The yields were equivalent to those of the groundnuts in the monoculture system (see Table 7). Some yield components, such as the number of pods, weight of pods and seed weight per plant, as well as 100 seed weight and seed yield per hectare, showed a tendency that groundnuts grown intercropping with one year-old oil palms had higher yield components than that of the groundnuts from the monoculture system.

Intercropping between oil palm - soybean and oil palm - groundnuts had land equivalent ratio (LER) of 4.10 and 3.30, respectively (see Table 8). These conditions indicated that the intercropping of oil palm - soybean and oil palm - groundnut would be more profitable than the cultivation of oil palms, soybeans and groundnuts in the monoculture. This was particularly because the LER in both the intercropping systems was more than 1 .

\section{Discussion}

At the young oil palm plantation areas, especially one year-old oil palms, the empty spaces between the rows of oil palms are still quite wide. At the time when the current study was carried out, the empty spaces were still left unplanted. In addition, the efficiency level of the uses of environmental resources, such as land, solar radiation, water, mineral nutrients and $\mathrm{CO}_{2}$, was still not optimal in the areas of the one year-old oil palm plantations (Tsubo et al., 2003; Szumigalski \& Acker, 2006; Aynehband et al., 2010; Filho et al., 2011). Planting annual food crops among the rows of the one year-old oil palms can provide the opportunity to improve the use of the environmental resources more efficiently in that area. In addition, the utilization of the empty space for planting annual food crops has a potential to increase the production of food.

At present, information regarding the use of technology for the empty spaces between the rows of the one year-old oil palms for food production is still limited. Therefore, studies that can gather appropriate package of technology associated with the planting of annual food crops between the rows of a year-old oil palm are 
required. These studies are intended to gather information that can be used to determine the annual food crops which produce high yields when intercropped with one year-old oil palms, but will not inhibit the growth rate and development of oil palms as the main crop at the same time. In addition, the study can also be used to collect data for the species of the annual food crops that have positive associations with oil palms, i.e. the growth and development of oil palms have actually been accelerated when grown together or along with these food crops. In particular, soybeans and groundnuts are types of the annual food crops which have the potential to be developed when intercropped with one year-old oil palms. Nevertheless, more in-depth studies are still needed to prove these findings.

Data may provide information which indicates that the growth of one year-old oil palms does not have problems when planted along with soybeans and groundnuts. The growth rate of one year-old oil palms intercropped with soybeans and groundnuts was also similar to that of oil palms in the monoculture system (see Table 3). In fact, all the growth components of oil palms actually indicate that intercropping with soybean and groundnut has the tendency to increase the growth rate of oil palms, particularly when intercropped with soybeans. In particular, intercropping with soybeans was found to have significantly improved the growth rate of the one year-old oil palms, as clearly seen from their trunk diameters.

Thus, growth acceleration was observed for the one year-old oil palms grown along with soybeans. Meanwhile, intercropping with groundnuts resulted in a similar growth rate for oil palms compared to those oil palms in the monoculture system (see Table 3). The positive effect of intercropping to the growth rate of oil palms occurred due to the fact that the two species of the annual food crops possess different shoot and root morphological characteristics. The shoots of oil palms with the size greater than those of the soybeans and groundnuts occupied the upper zone, while the soybeans and groundnuts with smaller shoot sizes occupied the lower zone (i.e. below the canopy of the oil palms). These conditions resulted in the absence of competition between the shoots of the one year-old oil palms and those of the soybeans and groundnuts in relation to the environmental resources, such as the above ground growing space, sunlight and $\mathrm{CO}_{2}$ (Govea \& Albrecht, 2005; Singer et al., 2006; Chianeh et al., 2011). In other words, the shoots of oil palms get the optimal growing space, sunlight and $\mathrm{CO}_{2}$.

The conditions that occur in the sub-soil surface were also found in line with the pattern of interaction between the shoots of oil palms with those of the soybeans and groundnuts above the soil surface. Hence, the morphological characters of the roots of oil palms are different with those of soybeans and groundnuts. Palm roots are apparently larger and longer and thus will occupy the lower layers of the soil, while the roots of soybeans and groundnuts are smaller and shorter and they will fill the upper soil layers that are near to the soil surface. These conditions will encourage the non- competition between the roots of oil palms and those of the soybeans and groundnuts in obtaining environmental resources, such as space, nutrients and water (Chen et al., 2004; Ross et al., 2004; Touzi et al., 2010; Yang et al., 2010). The roots of oil palms, soybeans and groundnuts get the optimal space, nutrients and water (Singer et al., 2006; Celette et al., 2009). The roots are capable to support the growth of oil palm shoots, so the growth of oil palms is equivalent to the palms of the monoculture system (Hinsinger, 2011).

Meanwhile, the one year-old oil palms, which are intercropped with soybeans and groundnuts, have the advantage for additional supply of nitrogen $(\mathrm{N})$ from soybeans and groundnuts (see Table 1). Soybeans and groundnuts are of the legume family, which have the ability to get free $\mathrm{N}$ from the air through a mutualism symbiotic with Rhizobium (Lauriault \& Kirksey, 2004; Matiru \& Dakora, 2004; Cardoso et al., 2007; Zhang et al., 2010; Abusuwar \& Omer, 2011). These conditions resulted in the increase of soil $\mathrm{N}$ content in the field planted with soybeans and groundnuts, i.e. intercropping field between oil palms - soybeans and oil palms groundnuts (Cardoso et al., 2007; Zhang et al., 2010; Abusuwar \& Omer, 2011). The additional supply of nitrogen from soybeans and groundnuts is sustained by oil palms by increasing the growth rate of their shoots.

Both the growth and yield of soybeans and groundnuts were also found to be the maximum when planted between the rows of the one year-old oil palms. The indications were the similar growth and yield variables between soybeans and groundnuts intercropped with oil palms and those in the monoculture system (see Tables 4 , 5,6 and 7). This occurred because of the positive interactions between soybeans - oil palms and groundnuts - oil palms. The positive interactions were also due to the different morphological characters between the shoots and roots of oil palms, soybeans and groundnuts. The shoot of soybeans and groundnuts could get enough growth space, solar radiation and $\mathrm{CO}_{2}$. In terms of solar radiation, the empty spaces between the rows of the one year-old oil palms were still very much open that the radiation could reach up to the land surface. Hence, solar radiation was still able to meet the needs of soybeans and groundnuts. Moreover, soybeans and groundnuts are C3 plants, which have the light reaction pathway in the photosynthesis following the Calvin's cycle. In general, crops in this particular plant group do not require full light intensity to be able to grow and develop normally 
(McKormic et al., 2006).

The maximum growth and yields of soybeans and groundnuts intercropped with one year-old oil palms were also supported by the differences in their root morphological characteristics. As indicated earlier, the roots of soybeans and groundnuts were found to occupy the upper layer of land, whereas the roots of oil palms occupied the lower layer. Soybean and groundnut get the supplies of water and mineral nutrients from the upper layer of land, while the oil palm got it from the lower layer of land. These conditions will not cause any competition between oil palms - soybeans or oil palms - groundnuts in relation to growth space, mineral nutrients and water. Instead, crops received sufficient level of their growing needs (Ghosh et al., 2006; Khan et al., 2007). This is what sustains the optimal growth and yield of soybeans and groundnuts when the plants are grown between the rows of one year-old oil palms.

Based on the LER, intercropping oil palms - soybeans and oil palms - groundnuts is the ideal pattern for intercropping because both kinds of intercropping have LER $>1$ (Table 8). The intercropping patterns of oil palms - soybeans and oil palms - groundnuts were also found to be more profitable than that of the monoculture systems for all the three crops. These conditions indicated that the inter-specific competition between one year-old oil palms and soybean and groundnut was rather minimal when compared to the intra-specific competition within the three crops (Khan et al., 2007). These situations or conditions have caused intercropping system to provide a better response when compared to the monoculture system. Therefore, intercropping between oil palms - soybeans and oil palms - groundnuts can be recommended for the areas where one year-old oil palms are grown.

\section{Conclusions}

Based on the findings of the current study, it can be stated that soybeans and groundnuts are eligible to be selected and grown as the annual food crops between the rows of one year-old oil palms. Soybeans and groundnuts could give high yields when planted between the rows of the one year-old oil palms, which are similar to the yields of those crops grown in the monoculture system. Moreover, the presence of soybeans and groundnuts between the rows of one year-old oil palms does not inhibit the growth rate and the development of oil palms as the main crop. On the contrary, there is a tendency for the oil palms planted with soybeans and groundnut to grow much faster than those grown in the monoculture system.

\section{Acknowledgments}

This research was funded by Faculty of Agriculture, Universitas Gadjah Mada under the Young Lecturer Research Grant Scheme (No. 2007-1). The authors would like to express their gratitude to Mr. Widodo for his assistance in the study.

\section{References}

Abera, T. \& D. Feyisa. (2008). Faba bean and field pea seed proportion for intercropping system in Horro Highlands of Western Ethiopia. Afr. Crop Sci. J., $16(4), \quad 243$ - 249. http://www.ajol.info/index.php/acsj/article/viewFile/54398/42916

Abusuwar, A. O. \& E. A. Omer. (2011). Effect of intercropping, phosphorus fertilization and rhizobium inoculation on the growth and nodulation of some leguminous and cereal forages. Agric. Biol. J. N. Am., 2(1), 109 - 124. http://scihub.org/ABJNA/PDF/2011/1/ABJNA-2-1-109-124.pdf

Amanullah, M. M., K. Vaiyapuri, A. Alagesan, E. Somasundaram, K. Sathyamoorth \& S. Pazhanivelan. (2006). Effect of intercropping and organic manures on the yield and biological efficiency of cassava intercropping system (Manihot esculenta Crantz.). Res. J. Agric. \& Biol. Sci., 2(5), 201 - 208. http://www.aensionline.com/rjabs/2006/201-208.pdf

Aynehband, A., M. Behrooz \& A. H. Afshar. (2010). Study of intercropping agroecosystem productivity influenced by different crops and planting rations. Am-Euras. J. Agric. \& Environ. Sci., 7(2), 163 - 169. http://www.idosi.org/aejaes/jaes7(2)/7.pdf

Cardoso, E. J. B. N., M. A. Nogueira \& S. M. G. Ferraz. (2007). Biological $\mathrm{N}_{2}$ fixation and mineral N in common bean-maize intercropping or sole cropping in southeastern Brazil. Expl. Agric., 43, 319 - 330. http://www.planta.cn/forum/files_planta/download_114.pdf

Celette, F., A. Findeling \& C. Gary. (2009). Competition for nitrogen in an unfertilized intercropping systems: the case of an association of grapevine and grass cover in a Mediterranean climate. Eur. J. Agron., 30(1), 41 - 51. http://publications.cirad.fr/une_notice.php?dk $=547300$

Chen, C., M. Westcott, K. Neill, D. Wichman \& M. Knox. (2004). Row configuration and nitrogen application 
for barley-pea intercropping in Montana. Agron. J. $\quad 96, \quad 1730 \quad-\quad 1738$. http://openagricola.nal.usda.gov/Record/IND43661774

Chianeh, E. R., A. D. M. Nassab, M. R. Shakiba, K. G. Golezani, S. Aharizad \& F. Shekari. (2011). Intercropping of maize (Zea mays L.) and faba bean (Vicia faba L.) at different plant population densities. Afr. J. Agric. Res., 6(7), 1786

1793.

http://www.academicjournals.org/ajar/PDF/pdf2011/4\%20Apr/Rezaei-Chianeh\%20et\%20al.pdf

Corley, R. H. V. \& P. B. Tinker. (2003). The palm oil. Berlin: Blackwell Publishing, 562pp. Germany.

Filho, A. B. C., B. L. A. Rezende, J. C. Barbosa \& L. C. Grangeiro. (2011). Agronomic efficiency of intercropping tomato and lettuce. An. Acad. Bras. Cienc., 83(3), 1109-1119. http://www.scielo.br/scielo.php?pid=S0001-37652011000300029\&script=sci_arttext

Ghosh, P. K., M. C. Manna, K. K. Bandyopadhyay, Ajay, A. K. Tripathi, R. H. Wanjari, K. M. Hati, A. K. Misra, C. L. Acharya \& A. Subba Rao. (2006). Interspecific interaction and nutrient use in soybean/sorghum $\begin{array}{lllll}\text { intercropping } \quad \text { system. } & \text { Agron. } & \text { J., }\end{array}$ http://www.mendeley.com/research/interspecific-interaction-and-nutrient-use-in-soybeansorghum-intercroppingsystem/

Govea, F. E. C. \& K. A. Albrecht. (2005). Mixtures of kura clover with small grains or italian ryegrass to extend the forage production season in the northern USA. Agron. J., 97, 131-136. http://mccc.msu.edu/\%5C/states/Wisconsin/Cereal_crops_an_Italian_Ryegrass_with_Kura.pdf

Haby, V. A., S. A. Stout, F. M. Hons \& A. T. Leonard. (2006). Nitrogen fixation and transfer in a mixed stand of alfalfa and bermudagrass. Agron. J., 98, 890-898. https://www.agronomy.org/publications/aj/articles/98/4/890

Hinsinger, P. (2011). P for two, sharing a scarce resouce - Soil phophorus acquisition in the rhizosphere of intercropped species. Plant Physiol., 156, 1078-1086. http://www.plantphysiol.org/content/156/3/1078.short

Khan, Z. R., C. A. O. Midega, A. Hassanali, J. A. Pickett \& L.J. Wadhams. (2007). Assessment of different legumes for the control of Striga hermonthica in maize and sorghum. Crop. Sci., 47, 730-734. http:/www.mendeley.com/research/assessment-of-different-legumes-for-the-control-of-striga-hermonthica-in-m aize-and-sorghum/

Lauriault, L. M. \& R. E. Kirksey. (2004). Yield and nutritive value of irrigated winter cereal forage grass-legume intercrops in the Southern High Plains, USA. Agron. J., 96, 352-358. https://www.agronomy.org/publications/aj/articles/96/2/352

Matiru, V. N. \& F. D. Dakora. (2004). Potential use of rhizobial bacteria as promoters of plant growth for increased yield in landraces of African ceral crops. Afr. J. Biotechnol., 3(1), 1-7. http://www.ajol.info/index.php/ajb/article/view/14908

McCormick, J.S., R. M. Sulc, D. J. Barker, \& J. E. Beuerlein. (2006). Yield and nutritive value of autumn-seeded winter-hardy and winter-sensitive annual forages. Crop. Sci., 46, 1981-1989. http://cat.inist.fr/?aModele=afficheN\&cpsidt=18159803

Ministry of Agriculture Indonesia (MoA). (2011). Plants statistics data. [Online] Available: http://aplikasi.deptan.go.id/bdsp/index.asp (October 26, 2011)

Palaniappan, S. P. (1985). Cropping system in the tropic, principle and management. New Delhi: Wiley Eastern Limited, 215pp. India.

Prasad, R. B. \& R. M. Brook. (2005). Effect of varying maize densities on intercropped maize and soybean in Nepal. Axpl. Agric., 41, 365 - 382. http://cat.inist.fr/?aModele=afficheN\&cpsidt=17020733

Rezig, M., A. Sahli, F. B. Jeddi \& Y. Harbaoui. (2010). Adopting intercropping system for potatoes as practice on drought mitigation under Tunisian conditions. Options Mediterraneennes, A (95), $329-334$. http://ressources.ciheam.org/om/pdf/a95/00801365.pdf

Rezvani, M., F. Zaefarian, M. Aghaalikhani, H. R. Mashhadi \& E. Zand. (2011). Investigation corn and soybean intercropping advantages in competition with redroot pigweed and jimsonweed. World Academy of Science, Engineering and Technology, 81, 350 - 352. http://www.waset.org/journals/waset/v81/v81-67.pdf

Ross, S. M., J. R. King, J. T. O’Donovan, \& D. Spaner. (2004). Intercropping berseem clover with barley and oat cultivars for forage. Agron. J., 96, $1719-1729$. http://cat.inist.fr/?aModele=afficheN\&cpsidt=16327279

SAS Institute Inc. (1990). SAS/STAT users guide. North Caroline: SAS Publishing, 848 pp. USA 
Singer, J. W., S. D. Logsdon \& D. W. Meek. (2007). Tillage and compost effects on corn growth, nutrient accumulation, and grain yield. Agron. $\quad$ J., $\quad 99, \quad 80 \quad-87$. http://ddr.nal.usda.gov/bitstream/10113/16059/1/IND43923743.pdf

Singer, J. W., M. D. Casler \& K. A. Kohler. (2006). Wheat effect on frost-seeded red clover cultivar $\begin{array}{llllllll}\text { establishment and } \quad \text { yield. } & \text { Agron. } & \text { J., } & 98, & 265 & - & 269 .\end{array}$ http://ddr.nal.usda.gov/bitstream/10113/3602/1/IND43801431.pdf

SMARTRI. (2005). Technical guideline of cultivation of oil palm. Jakarta: PT. SMART Tbk, 78pp. Indonesia

Szumigalski, A. R. \& R. C. V. Acker. (2006). Nitrogen yield and land use efficiency in annual sole crops and $\begin{array}{llllll}\text { intercrops. } & \text { Agron. } & \text { J., } & 98, & 1030 & -\end{array}$ http://www.mendeley.com/research/nitrogen-yield-and-land-use-efficiency-in-annual-sole-crops-and-intercrops/

Touzi, I. S., S. De Tourdonnet, M. Launay \& T. Dore. (2010). Does intercropping winter wheat (Triticum aestivum) with red fescue (Festuca rubra) as a cover crop improve agronomic and environmental performance? A modeling approach. Field Crops $\quad$ Res., $\quad 116, \quad 218 \quad-229$. http://linkinghub.elsevier.com/retrieve/pii/S0378429009003177

Tsubo, M., E. Mukhala, H. O. Ogindo \& S. Walker. (2003). Productivity of maize-bean intercropping in a semi-arid region of South Africa. Water SA., 29(4), $381 \quad-\quad 388$. http:/www.ajol.info/index.php/wsa/article/view/5038/12614

Yang, C. H., Q. Chai \& G. B. Huang. (2010). Root distribution and yield responses of wheat/maize intercropping to alternate irrigation in the arid areas of northwest China. Plant Soil Environ., 56(6), 253 - 262. http://agriculturejournals.cz/publicFiles/21435.pdf

Zhang, N. N., Y. M. Sun, L. Li, E. T. Wang, W. X. Chen \& H. L. Yuan. (2010). Effects of intercropping and Rhizobium inoculation on yield and rhizosphere bacterial community of faba bean (Vicia faba L.). Biol. Fertil. Soils, 46, 625 - 639. http://www.springerlink.com/index/m71403335365u346.pdf

Table 1. The analysis of some chemicals and physicals soil properties

\begin{tabular}{llll}
\hline No & Chemical and Physical Soil Properties & Value & Criteria \\
\hline 1 & $\mathrm{pH}$ & 6.46 & Intermediate \\
2 & $\mathrm{C}(\%)$ & 1.83 & Low \\
3 & $\mathrm{~N}(\%)$ & 0.69 & High \\
4 & $\mathrm{P}_{2} \mathrm{O}_{5}(\mathrm{mg} / 100 \mathrm{~g})$ & 6.07 & Very low \\
5 & $\mathrm{~K}(\mathrm{meq} / 100 \mathrm{~g})$ & 0.48 & Intermediate \\
6 & OM $(\%)$ & 3.10 & Low \\
7 & $\mathrm{CEC}(\mathrm{meq} / 100 \mathrm{~g})$ & 30.93 & High \\
8 & Sand $(\%)$ & 33.01 & - \\
9 & Clay $(\%)$ & 34.33 & - \\
10 & Dust $(\%)$ & 32.66 & - \\
11 & Texture & Clay-loam & - \\
\hline
\end{tabular}

The field has an optimal $\mathrm{pH}$, nitrogen, potassium and cation exchange capacity for the growth and development of oil palms, as well as the annual food crops. The contents of phosphorus, carbon and organic matter in the field were not ideal to support plant growth and development because the values were quite low. 
Table 2. Temperature, humidity, light intensity and rainfall at research site

\begin{tabular}{|c|c|c|c|c|}
\hline \multicolumn{2}{|c|}{ Time of observation } & \multirow{2}{*}{$\begin{array}{l}\text { Temperature }\left({ }^{\circ} \mathrm{C}\right) \\
30.50\end{array}$} & \multirow{2}{*}{$\begin{array}{c}\text { Humidity (\%) } \\
51.30\end{array}$} & \multirow{2}{*}{$\begin{array}{c}\text { Light intensity } \\
(\%)\end{array}$} \\
\hline \multirow{3}{*}{$\begin{array}{l}\text { Beginning of the } \\
\text { research }\end{array}$} & Morning & & & \\
\hline & Noon & 29.50 & 52.00 & 91.00 \\
\hline & Afternoon & 28.50 & 52.00 & 66.50 \\
\hline \multirow{3}{*}{ End of the research } & Morning & 29.50 & 55.50 & 13.10 \\
\hline & Noon & 36.20 & 42.25 & 88.30 \\
\hline & Afternoon & 26.30 & 76.80 & 85.20 \\
\hline & & $\begin{array}{l}\text { Number of rainy days (per } \\
\text { month) }\end{array}$ & $\begin{array}{l}\text { Rainfall (mm/ } \\
\text { month) }\end{array}$ & \\
\hline \multicolumn{2}{|l|}{ September (2007) } & 2 & 7 & \\
\hline \multicolumn{2}{|l|}{ October (2007) } & 3 & 110 & \\
\hline \multicolumn{2}{|l|}{ November (2007) } & 7 & 159 & \\
\hline \multicolumn{2}{|l|}{ December (2007) } & 25 & 536 & \\
\hline \multicolumn{2}{|l|}{ January (2008) } & 18 & 494 & \\
\hline
\end{tabular}

The high temperature and low humidity at the research site are not ideal for the growth and development of oil palms, as well as annual food crops. The research site has a high level of light intensity and rainfalls, so the research site is ideal to support the growth and development of oil palms and the annual food crops from both the environmental variables.

Table 3. The growth of oil palms in monoculture and intercropped with soybeans and groundnuts

\begin{tabular}{|c|c|c|c|}
\hline The growth of oil palms & $\begin{array}{l}\text { Oil palms }+ \\
\text { Soybeans }\end{array}$ & $\begin{array}{l}\text { Oil palms }+ \\
\text { Groundnuts }\end{array}$ & $\begin{array}{l}\text { Oil palm in the } \\
\text { monoculture system }\end{array}$ \\
\hline $\begin{array}{l}\text { LAI, } 6 \text { weeks after planting the annual } \\
\text { food crops }\end{array}$ & $1.49 \mathrm{a}$ & $1.46 \mathrm{a}$ & $1.39 \mathrm{a}$ \\
\hline $\begin{array}{l}\text { LAI, } 10 \text { weeks after planting the annual } \\
\text { food crops }\end{array}$ & $1.71 \mathrm{a}$ & $1.69 \mathrm{a}$ & $1.64 \mathrm{a}$ \\
\hline NAR $\left(\mathrm{g} \mathrm{dm}^{-2}\right.$ week $\left.^{-1}\right)$ & $75.07 \mathrm{a}$ & $47.35 \mathrm{a}$ & $42.17 \mathrm{a}$ \\
\hline CGR $\left(\mathrm{g} \mathrm{m}^{-2}\right.$ week $\left.^{-1}\right)$ & $1.96 \mathrm{a}$ & $1.60 \mathrm{a}$ & $1.20 \mathrm{a}$ \\
\hline $\begin{array}{l}\text { Stem dry weight }(\mathrm{kg}), 6 \text { weeks after } \\
\text { planting the annual food crops }\end{array}$ & $0.31 \mathrm{a}$ & $0.29 \mathrm{a}$ & $0.28 \mathrm{a}$ \\
\hline $\begin{array}{l}\text { Stem dry weight }(\mathrm{kg}), 10 \text { weeks after } \\
\text { planting the annual food crops }\end{array}$ & $0.35 \mathrm{a}$ & $0.30 \mathrm{a}$ & $0.29 \mathrm{a}$ \\
\hline $\begin{array}{l}\text { Leaf dry weight }(\mathrm{kg}), 6 \text { weeks after } \\
\text { planting the annual food crops }\end{array}$ & $2.59 \mathrm{a}$ & $2.56 \mathrm{a}$ & $2.45 \mathrm{a}$ \\
\hline $\begin{array}{l}\text { Leaf dry weight }(\mathrm{kg}), 10 \text { weeks after } \\
\text { planting the annual food crops }\end{array}$ & $0.35 \mathrm{a}$ & $0.30 \mathrm{a}$ & $0.29 \mathrm{a}$ \\
\hline $\begin{array}{l}\text { Plant dry weight }(\mathrm{kg}), 6 \text { weeks after } \\
\text { planting the annual food crops }\end{array}$ & $2.89 \mathrm{a}$ & $2.80 \mathrm{a}$ & $2.80 \mathrm{a}$ \\
\hline $\begin{array}{l}\text { Plant dry weight }(\mathrm{kg}), 10 \text { weeks after } \\
\text { planting the annual food crops }\end{array}$ & $3.01 \mathrm{a}$ & $2.89 \mathrm{a}$ & $2.84 \mathrm{a}$ \\
\hline
\end{tabular}


Table 4. The growth of soybeans in the intercropping and monoculture systems

\begin{tabular}{lcr}
\hline \multicolumn{1}{c}{ The growth of soybean } & $\begin{array}{c}\text { Intercropping } \\
\text { with oil palm }\end{array}$ & Monoculture \\
\hline Number of leaves, 6 weeks after planting & $25.1 \mathrm{a}$ & $17.13 \mathrm{a}$ \\
Number of leaves, 10 weeks after planting & $65.06 \mathrm{a}$ & $37.86 \mathrm{a}$ \\
LAI, 6 weeks after planting & $0.48 \mathrm{a}$ & $0.25 \mathrm{a}$ \\
LAI, 10 weeks after planting & $3.29 \mathrm{a}$ & $1.87 \mathrm{a}$ \\
NAR $\left(\mathrm{g} \mathrm{dm}^{-2}\right.$ week $\left.^{-1}\right)$ & $0.51 \mathrm{a}$ & $0.65 \mathrm{a}$ \\
CGR $\left(\mathrm{kg} \mathrm{m}^{-2}\right.$ week & \\
Total root length $(\mathrm{dm}), 6$ weeks after planting & $0.36 \mathrm{a}$ & $0.28 \mathrm{a}$ \\
Total root length $(\mathrm{dm}), 10$ weeks after planting & $3.8 \mathrm{a}$ & $4.3 \mathrm{a}$ \\
Root dry weight $(\mathrm{g}), 6$ weeks after planting & $10.3 \mathrm{a}$ & $8.2 \mathrm{a}$ \\
Root dry weight $(\mathrm{g}), 10$ weeks after planting & $3.22 \mathrm{a}$ & $1.77 \mathrm{a}$ \\
Plant dry weight $(\mathrm{g}), 6$ weeks after planting & $7.86 \mathrm{a}$ & $3.1 \mathrm{a}$ \\
Plant dry weight $(\mathrm{g}), 10$ weeks after planting & $19.36 \mathrm{a}$ & $11.13 \mathrm{a}$ \\
Plant height $(\mathrm{cm}), 6$ weeks after planting & $74.64 \mathrm{a}$ & $44.42 \mathrm{a}$ \\
Plant height $(\mathrm{cm}), 10$ weeks after planting & $21.81 \mathrm{a}$ & $14.39 \mathrm{a}$ \\
Stem diameter $(\mathrm{cm}), 6$ weeks after planting & $48.40 \mathrm{a}$ & $36.12 \mathrm{a}$ \\
Stem diameter $(\mathrm{cm}), 10$ weeks after planting & $0.35 \mathrm{a}$ & $0.24 \mathrm{a}$ \\
\hline
\end{tabular}

Means in the same row, followed by different letters, are significantly different based on the LSD test $(p \leq 0.05)$

Table 5. Yield components of the soybeans intercropped with oil palms and in the monoculture system

\begin{tabular}{lcc}
\hline \multicolumn{1}{c}{ Yield components } & $\begin{array}{c}\text { Intercropped with } \\
\text { oil palms }\end{array}$ & Monoculture \\
\hline Number of pods per plant & $49.66 \mathrm{a}$ & $40.30 \mathrm{a}$ \\
Weight of pods per plant (g) & $14.02 \mathrm{a}$ & $12.02 \mathrm{a}$ \\
Seed weight per plant (g) & $11.26 \mathrm{a}$ & $9.36 \mathrm{a}$ \\
100 seed weight (g) & $9.10 \mathrm{a}$ & $8.78 \mathrm{a}$ \\
Seed yield per hectare (ton/ha) & $1.18 \mathrm{a}$ & $1.03 \mathrm{a}$ \\
Harvest index & $0.18 \mathrm{a}$ & $0.22 \mathrm{a}$ \\
\hline
\end{tabular}

Means in the same row, followed by different letters, are significantly different based on the LSD test $(p \leq 0.05)$ 
Table 6 . The growth of groundnuts grown in the intercropping and monoculture systems

\begin{tabular}{lcr}
\hline \multicolumn{1}{c}{ The growth of groundnut } & $\begin{array}{c}\text { Intercropping } \\
\text { with oil palm }\end{array}$ & Monoculture \\
\hline Number of leaves, 6 weeks after planting & $26.36 \mathrm{a}$ & $18.36 \mathrm{a}$ \\
Number of leaves, 10 weeks after planting & $59.60 \mathrm{a}$ & $41.30 \mathrm{a}$ \\
LAI, 6 weeks after planting & $0.13 \mathrm{a}$ & $0.11 \mathrm{a}$ \\
LAI, 10 weeks after planting & $3.17 \mathrm{a}$ & $2.13 \mathrm{a}$ \\
NAR (g dm ${ }^{-2}$ week $\left.^{-1}\right)$ & $0.92 \mathrm{a}$ & $0.73 \mathrm{a}$ \\
CGR (kg m ${ }^{-2}$ week $\left.{ }^{-1}\right)$ & $0.53 \mathrm{a}$ & $0.27 \mathrm{a}$ \\
Total root length (dm), 6 weeks after planting & $2.83 \mathrm{a}$ & $2.92 \mathrm{a}$ \\
Total root length (dm), 10 weeks after planting & $11.68 \mathrm{a}$ & $9.43 \mathrm{a}$ \\
Root dry weight $(\mathrm{g}), 6$ weeks after planting & $1.96 \mathrm{a}$ & $1.54 \mathrm{a}$ \\
Root dry weight $(\mathrm{g}), 10$ weeks after planting & $17.93 \mathrm{a}$ & $13.04 \mathrm{a}$ \\
Plant dry weight $(\mathrm{g}), 6$ weeks after planting & $5.92 \mathrm{a}$ & $4.23 \mathrm{a}$ \\
Plant dry weight $(\mathrm{g}), 10$ weeks after planting & $75.05 \mathrm{a}$ & $39.78 \mathrm{a}$ \\
Plant height $(\mathrm{cm}), 6$ weeks after planting & $10.55 \mathrm{a}$ & $7.85 \mathrm{a}$ \\
Plant height $(\mathrm{cm}), 10$ weeks after planting & $27.12 \mathrm{a}$ & $16.10 \mathrm{~b}$ \\
Stem diameter $(\mathrm{cm}), 6$ weeks after planting & $0.41 \mathrm{a}$ & $0.32 \mathrm{~b}$ \\
Stem diameter $(\mathrm{cm}), 10$ weeks after planting & $0.56 \mathrm{a}$ & $0.45 \mathrm{~b}$
\end{tabular}

Means in the same row, followed by the different letters, are significantly different, based on the LSD test $(p \leq$ $0.05)$.

Table 7. Yield components of the groundnuts intercropped with oil palms and in monoculture

\begin{tabular}{lcc}
\hline \multicolumn{1}{c}{ Yield components } & $\begin{array}{c}\text { Intercropped with oil } \\
\text { palms }\end{array}$ & Monoculture \\
\hline Number of pods per plant & $15.53 \mathrm{a}$ & $12.66 \mathrm{a}$ \\
Weight of pods per plant $(\mathrm{g})$ & $20.40 \mathrm{a}$ & $17.74 \mathrm{a}$ \\
Seed weight per plant $(\mathrm{g})$ & $15.20 \mathrm{a}$ & $12.54 \mathrm{a}$ \\
100 seed weight $(\mathrm{g})$ & $40.66 \mathrm{a}$ & $36.17 \mathrm{a}$ \\
Seed yield per hectare (ton/ha) & $1.32 \mathrm{a}$ & $1.22 \mathrm{a}$ \\
Harvest index & $0.30 \mathrm{~b}$ & $0.45 \mathrm{a}$ \\
\hline
\end{tabular}

Means in the same row, followed by the different letters, are significantly different, based on the LSD test ( $p \leq$ $0.05)$.

Table 8. Land use efficiency in the intercropping of oil palms - soybeans and oil palms - groundnuts

\begin{tabular}{ll}
\hline \multicolumn{1}{c}{ Intercropping } & \multicolumn{1}{c}{ Land use efficiency } \\
\hline Oil palm - soybean & 4.10 \\
Oil palm - groundnut & 3.30 \\
\hline
\end{tabular}



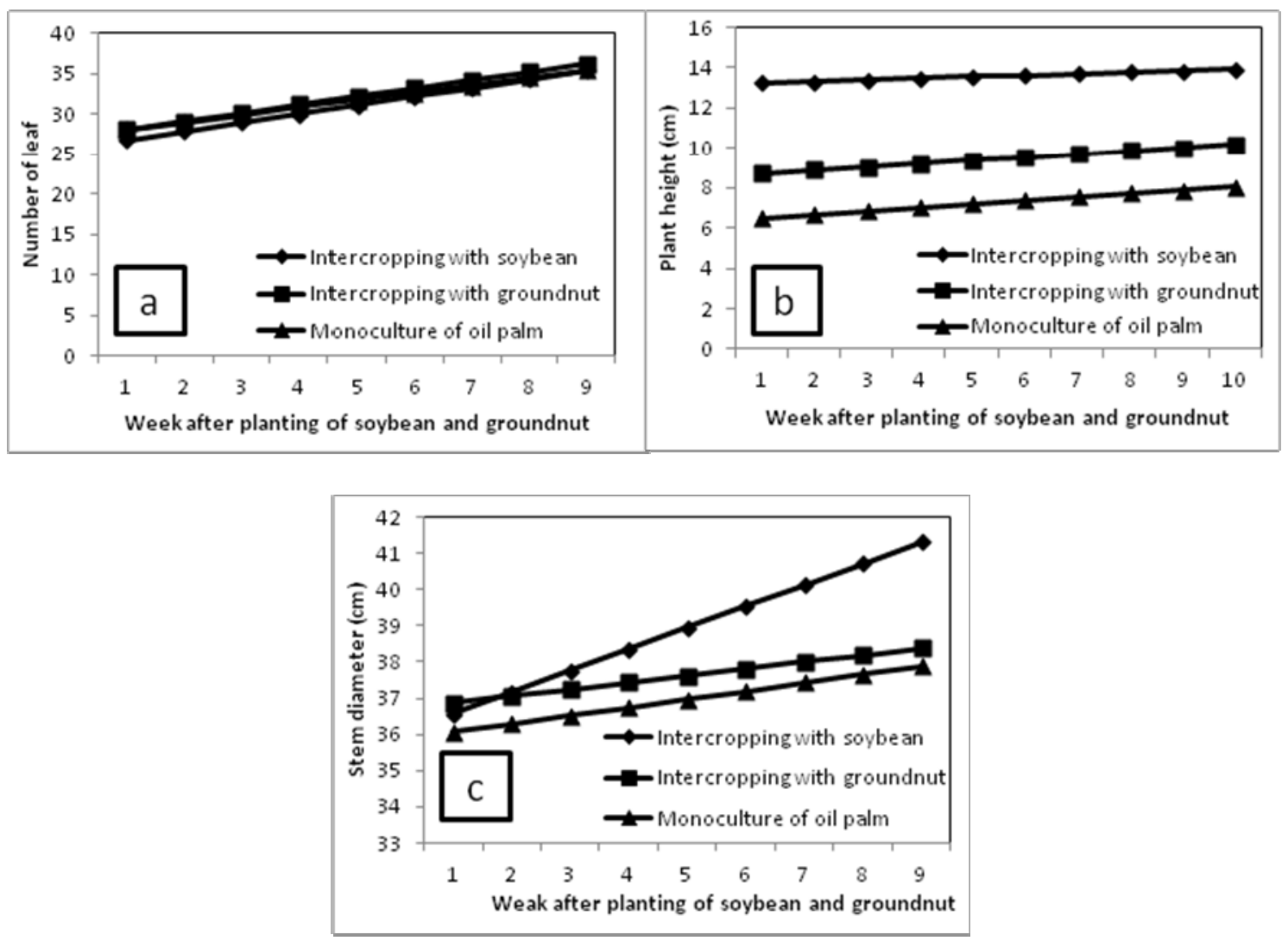

Figure 1. Leaf number (a), plant height (b) and stem diameter (c) of oil palm, planted in monoculture and intercropped with soybeans and groundnuts

The number of leaves of oil palm planted in the monoculture and intercropping areas was similar, either intercropped with soybeans or groundnuts. Oil palms intercropped with soybeans have higher trunks compared to those intercropped with groundnut or in the monoculture. This finding could not be used as an indicator showing that the intercropping system has a positive effect on the height rate of oil palms. This is particularly because oil palms intercropped with soybeans were initially higher than those that were intercropped with groundnuts or in monoculture of oil palms. The significant effect of the planting pattern could be detected in the diameter of oil palm trunks. Oil palms that were intercropped with soybeans were observed to have higher stem diameter compared to those intercropped with groundnuts or in monoculture. 